\title{
THE IMPACT OF PROFICIENCY LEVEL ON RECEPTIVE AND PRODUCTIVE VOCABULARY OF EFL LEARNERS
}

To know a word means both recognizing and using it correctly (Pignot-Shahov, 2012). The scarcity of the research and the inconsistent reports about the nature of the relationship between receptive $(R)$ and productive $(P)$ vocabulary knowledge indicate the complexity of this issue. Therefore, the present study investigated the relationship between these two types of English vocabulary knowledge as a whole and also in different frequency bands, across two proficiency levels. Version A of the R and P Vocabulary Levels Tests were distributed among 100 EFL learners of two proficiency levels. It was found that $R$ vocabulary size was always greater than the $P$ one, and that the gap between them widened as the frequency of words decreased. Although the participants progressed in $R$ and $P$ vocabulary knowledge, the proficiency level did not make any significant difference in the nature of the relationship between $R$ and $P$ vocabularies. It was concluded that the EFL context can be an important factor that hinders the turning of $R$ vocabulary into $P$ one.

Keywords: receptive vocabulary, productive vocabulary, Vocabulary Level Test, EFL Learners.

\section{Introduction}

Unlike early years of second language acquisition research, up to the 1980 s, that grammar was the dominant area of the study, learning vocabulary is an essential part of learning a language and today's world necessitates the use of English vocabulary. In the last three decades, vocabulary has grabbed the attention of the most researchers and it has become the central part of theories like the Lexical Learning Hypothesis according to which "vocabulary knowledge is indispensable to acquire grammar" (Malvern et al. 2008, p. 270 as cited in Pignot-Shahov, 2012). Moreover, many years ago, Wilkins (1972, p. 111) has strongly pointed to the importance of the vocabulary by stating that 'without grammar very little can be conveyed, without vocabulary nothing can be conveyed'. There is a strong bond between vocabulary knowledge and different measures of language proficiency as a whole and its various skills. It has been found that vocabulary knowledge can predict success in reading (Laufer, 1992; Qian \& Schedl, 2004), listening (Stæhr, 2009), speaking (Hilton, 2008; Yu, 2010), writing (Laufer \& Nation, 1995; Yu 2010) and in general academic performance (Harrington \& Carey, 2009). Alderson (2005, p. 88) has claimed that 'the size of one's vocabulary is relevant to one's performance on any language test'.

Although the importance of vocabulary knowledge is confirmed by researchers, the number of words that native and non-native speakers need to know is not determined unanimously yet. For instance, Schmitt (2010) remarks that despite the fact that native speakers will always vary in their vocabulary size to some extents; a range of 16,000-20,000 word families seems a fair estimate of the vocabulary size for educated native speakers while Nation (2006), using word lists based on the Wellington Corpus of Spoken English, calculated that 6,000-7,000 word families are required from L2 learners to use English well.
Another debatable issue is what the construct of word knowledge is. To conduct a research on vocabulary acquisition, we need to have a definition of lexical knowledge to determine what to investigate and how to measure it. However, 'no clear and unequivocal consensus exists as to the nature of lexical knowledge' (Laufer \& Paribakht, 1998, p. 366). According to Nation (2001), words are not isolated units of the language, but fit into many interrelated systems and levels, and that is why there is a lot to know about a word and there are many degrees of knowing. Schmitt (2010, p. 79) contends that '[v]ocabulary knowledge is multifaceted, and contains a number of interrelated, though separable, aspects'. Therefore, vocabulary researchers need to carefully consider which aspects they are going to measure in their studies.

The complex vocabulary knowledge construct is divided into different categories by different researchers. Anderson and Freebody (1981) have distinguished between breadth and depth of word knowledge. The number of words known by a learner is breadth of knowledge and what a learner knows about different aspects of these words is depth of knowledge. Another common way for dividing vocabulary knowledge is to categorize word knowledge into receptive or passive knowledge and productive or active knowledge. Nation (1990) defines receptive vocabulary use as perceiving the word form while listening or reading and retrieving its meaning, and productive vocabulary use as retrieving and producing the appropriate spoken or written form of a word. ledge

Receptive and productive distinction in lexical know-

Mostly, the distinction between receptive and productive knowledge is considered as the distinction between receptive skills (listening and reading) and productive skills (speaking and writing) (e.g. Crow, 1986; Laufer \& Goldstein, 2004). According to Nation (2001), the 
terms "receptive" and "productive" are not completely suitable because there are productive features in the receptive skills since when we listen or read we produce meaning. As Milton (2009, p. 13) has pointed out, 'good passive skills often require the reader or the listener to actively anticipate the words that will occur'.

Not all researchers define the receptive/productive dichotomy in the same way, and it has created problems making comparisons between these two kinds of knowledge (Read, 2000). Corson (1995) uses the terms "active" and "passive" to refer to productive and receptive vocabularies, and his description is strongly based on the idea of use and not solely on degrees of knowledge. Also, Laufer, Elder, Hill, and Congdon (2004) describe Receptive knowledge as retrieval of the word's form, and productive knowledge as retrieval of the word's meaning. Likewise, Webb (2008) defines Receptive vocabulary knowledge as the ability to recognize the form of a word and to define or find a synonym for it, while Productive vocabulary is the ability to recall the form and meaning of a foreign language word. These definitions restrict the concept of Receptive and Productive vocabulary knowledge to the form and meaning aspects.

However, Henriksen (1999) categorizes lexical knowledge in three components: 1) a partial-to-precise knowledge dimension where levels of knowledge are operationalized as degrees of understanding; 2) a depthof-knowledge dimension which reveals the multi-aspect nature of word knowledge, and extends to a word's syntagmatic and paradigmatic relations with other words; and 3) a receptive-productive dimension which refers to the mastery levels of vocabulary knowledge reflected in the learners' comprehension and productive ability.

Additionally, Nation (2001) distinguished the three following types of knowledge: knowledge of form, meaning and use, and then subdivided each of these three categories into three subcategories. For instance, the knowledge of form is further divided into spoken, written and word parts. Nation suggests that receptive and productive knowledge of a word should cover all aspects of what is involved in knowing a word. In other words, each of the aspects in the partial-precise and depth dimensions can be mastered at a receptive or productive level for use (Zhong, 2012). Therefore, Zhong (2012, p. 29) adapting Nation's definition of receptive and productive vocabulary knowledge, argues that 'receptive vocabulary knowledge can be conceptualized as the comprehension ability in reading and listening, and productive vocabulary knowledge can be conceptualized as the ability to apply the word appropriately to fit into a context in writing and speaking'.

Receptive and productive knowledge: a continuum or dichotomous units

As Laufer and Goldstein (2004) have pointed out, another debatable issue about the receptive and productive vocabulary knowledge is that whether the distinction between these two is dichotomous or it constitutes a continuum. Some researchers such as Melka (1997) suggest that they are placed on a continuum. To put it in other words, as learners learn about lexical items, Receptive knowledge gradually moves toward Productive knowledge. Although this viewpoint is confirmed by many researchers, the threshold at which receptive knowledge turns into productive is not determined (Laufer \& Goldstein, 2004; Read, 2000; Schmitt, 2010). On the other hand, Meara (1997) suggests that the two types of knowledge represent different association types between lexical items rather than being on a continuum. He believes that a productive knowledge of words needs a connection to productive items, whereas receptive knowledge of words is not connected to any words in the lexicon; moreover, in this view no progression is seen from a receptive to a productive state (Pignot-Shahov, 2012). However, all researchers confirm the existence of the receptive and productive dimension though they diverge in their ideas about the nature of vocabulary knowledge.

Empirical Studies on receptive / productive relationship

Exploring the relationship between receptive and productive vocabulary is called an "intriguing area" by Henriksen \& Haastrup (Henriksen \& Haastrup, 1998, p. 77). However, this area is scarcely explored and the statements about this relationship have been vague and unsubstantiated (Laufer \& Paribakht, 1998). Many research findings show that L2 learners' Receptive vocabulary size is larger than their Productive one (Laufer, 1998; Laufer \& Goldstein, 2004; Laufer \& Paribakht, 1998; Webb, 2008). It is assumed that gains in Receptive vocabulary knowledge often appear before Productive development (Melka, 1997).

However, there is no conclusive demonstration of the nature of the relationship between receptive and productive vocabulary knowledge, whether the gap between them is consistent or changes overtime. For instance, Wei (2007) mentioned that the results of the vocabulary test he used reflected only the students' passive knowledge and told nothing about the nature of this relationship. Also, regarding the extent of the gap between the two types of vocabulary, discrepancies have been reported. For example, it was found by Laufer (2005) that only $16 \%$ of receptive vocabulary was known productively at the 5,000 frequency level and $35 \%$ at the 2,000 level while other studies concluded that around one-half to three-quarters of receptive vocabulary is known productively (Fan, 2000; Laufer \& Paribakht, 1998). In general, Nation (1990, p.48) has stated that "rough estimates indicate that learning a word productively is $50 \%$ to $100 \%$ more difficult than learning it receptively".

Laufer (1998) as one of the forerunners in investigating this topic, compared the development of passive and active vocabulary knowledge in Grade 10 and Grade 11 Israeli EFL learners using three different types of tests i.e., "passive", "controlled active" and "free active" tests. The results revealed that the three dimensions of lexical knowledge developed at different rates as learners proceeded in their L2 learning. Also, the progression in passive vocabulary size was more than controlled active one with an addi- 
tional year of instruction while free active vocabulary did not progress at all. In 1998, Laufer and Paribakht using the same three measures examined $79 \mathrm{EFL}$, and $103 \mathrm{ESL}$ learners at different proficiency levels. The results showed that the three dimensions of vocabulary knowledge developed at different rates. Active, particularly free active vocabulary, developed more slowly and less predictably than the passive vocabulary did. They also concluded that the passive/active vocabulary gap was smaller in the foreign language than in the L2 context. Fan (2000) conducted another study on 138 freshmen students in Hong Kong University. The results did not show any consistent relationship between language proficiency and the two types of vocabulary knowledge since more proficient students were found to have a larger passive vocabulary while the result was inconclusive regarding their ability to recall more of the words they can recognize.

Later, Laufer et al. (2004) researched four modalities of vocabulary knowledge using a monolingual test. Their results showed that active recall was the most difficult mode followed by passive recall and with active and passive recognition being equally the easiest modes. In a follow-up study to Laufer et al.'s (2004), Laufer and Goldstein (2004) conducted a research using a bilingual test this time with the same target word list as the monolingual test. The results showed that active recall was the most difficult mode followed by passive one, active recognition and passive recognition, and this hierarchy was seen in all frequency levels. Additionally, Zhong and Hirsh (2009) revealed a different developmental pattern in which productive vocabulary size grew faster than receptive vocabulary size after a four-month classroom instruction period among a group of intermediate Chinese students. Nemati (2010) also examined this relationship across different years of school instruction on 100 Indian ESL learners and it was found that the ratio between the two types of knowledge increased from lower to higher levels, and also despite students' progression in active and passive vocabulary knowledge, this progress was only significant for passive vocabulary not for the active one after years of instruction. Therefore, Nemati drew the conclusion that the improvement can be justified by the ESL environment not by years of instruction.

\section{The Current Study}

Every language teacher has experienced learners' understanding of lexical items when listening or reading, but not being able to produce those items in their speech or writing. Therefore, determining how much vocabulary learners know passively, and how much vocabulary learners can potentially produce would be of great pedagogical value. Moreover, vocabulary knowledge of any kind, passive or active, is strongly dependent on the educational curriculum, contexts in which learners receive and use the vocabulary, and their proficiency level. On the one hand, the question that if the proficiency levels of language learners and also the context of L2 learning has any effect on the nature of the relationship between receptive and productive vocabulary knowledge is investigated by just a few studies, and on the other hand, the inconsistent results mentioned above indicate the difficulties and confusion involved in dealing with the receptive/productive issue. So the purpose of the current study is to find out the relationship between Receptive and Productive vocabulary knowledge of Iranian EFL learners and also to observe the changes that occur in this relationship as the proficiency level of the learners increases. Here, it is intended to answer the following specific research questions:

1) What is the relationship between learners' Receptive and Productive vocabulary knowledge as a whole and at different frequency levels? Is this relationship similar or different at low and high proficiency levels?

2) Does the relationship between learners' Receptive and Productive vocabulary differ significantly across different proficiency levels?

\section{Methodology \\ Participants}

The participants of the present study comprised 100 university students including 41 males and 59 females with the age range of 19-32 majoring in English literature and English translation. Actually, 132 participants were selected initially to be studied, but some of them were excluded from the study after giving the placement test and some others were absent in one of the sessions of the testing and their scores were eliminated from the dataset. Thus, the scores of 100 participants were utilized in statistical analysis. In this study, the participants were divided into two groups - high and low proficient - based on two criteria. The first criterion for grouping the participants was their educational years at the university. It was attempted to choose low-proficient learners from freshman and sophomore students, and high-proficient ones from senior students. The second grouping criterion was the scores of the participants on Oxford Placement Test. This test consisted of 60 items, and the participants scoring from 20-40 were placed in low-proficiency group and the participants with the score range of 40-60 were grouped as high-proficient.

Since all the participants were university students, they had the experience of studying English in junior high school and high school. In addition, they were screened by a university entrance exam, and after being accepted in the university they studied all subjects of general English, literature, linguistics, and translation. Moreover, the participants' background languages were Persian, Turkish, or Kurdish.

\section{Instruments}

In this study, two vocabulary tests were used to measure Receptive and Productive aspects of the participants' vocabulary knowledge. In addition, a placement test was used at the beginning of the study for placing the participants into two proficiency groups. The features of these three instruments are represented in the following:

Quick Placement Test (version 1). In order to determine the proficiency level of the participants at the beginning of the study, a Placement Test was given to them. It is developed and published by Oxford University Press and University of Cambridge Local Examinations Syndicate (UCLES) 
in 2001. This test has two versions but only version 1 was used in this study. The Placement Test has 60 multiple choice items and the allocated time is 30 minutes mentioned in the cover page of the test. In addition, different levels that test takers can be placed in according to their score range is provided at the end of the test. These levels are based on Cambridge diplomas (KET, PET, FCE, CAE, CPE) ranging from A1 to C2 level.

Receptive Vocabulary Level Test (version A). The test which was originally produced and revised by Nation (1983 \& 1990) measures the size of passive vocabulary knowledge of students based on words from five frequency levels, i.e. 2,000, 3,000, 5,000, Academic and 10,000. The Vocabulary Level Test which was used in this study was one of the equivalent forms of the original one revised and validated by Schmitt, Schmitt, and Clapham (2001). Many researchers have checked the reliability and the validity of the two versions of this test, and the one of them which is mostly cited is conducted by Schmitt et al. (2001). They found out that both versions are reliable, valid, and equivalent.

Each section is made up of ten three-item clusters. The total possible score for each section is 30 , and the total possible score for the whole test is 150 . The Vocabulary Levels Test used word-definition matching format to require testtakers to match the words to the definitions. The following illustrates an example of one of clusters in this test:

You must choose the right word to go with each meaning. Write the number of that word next to its meaning.

1. apparatus

2. compliment

3. ledge

4. revenue

__expression of admiration

5. scrap

6. tile

Productive Vocabulary Levels Test (Version A). This test was developed by Laufer and Nation (1999) in four parallel forms, and like Receptive Vocabulary Levels Test discussed above, it uses the same frequency bands. The test has 18 items at each of the 2000, 3000, 5000, University Word List (UWL), and 10000 word levels (90 items in total). Test Version A uses the items from the original Levels Test. It has three parallel test versions which are developed using the items from the three parallel versions of the Levels Test made by Norbert Schmitt. Regarding the reliability and validity feature of this test, Laufer and Nation (1999) conducted a study and strongly claimed that the Productive Vocabulary Levels Test is a reliable, valid and practical measure of vocabulary growth, and it is an additional quantitative measure which enables researching important issues in vocabulary acquisition.

For each item, a meaningful sentence context is presented and the first letters of the target item are also provided to prevent the test-takers from filling in another semantically appropriate word coming from a different frequency level. It is said that this test format is similar to the C-test developed by Klein-Braley and Raatz (1984), but there are also some differing points. The context provided for each vocabulary in this test is one sentence rather than paragraph, and the cues are not always half a word provided in C-test. According to Laufer and Nation (1999), because the test is of productive vocabulary ability, it is better to provide the minimal number of letters that would disambiguate the cue. They clarify the process in a way that if for example two letters could elicit two possible words in a sentence, one more letter was added to eliminate this possibility. Furthermore, unlike C-test, the size of the underlined space at the end of the incomplete word does not indicate the number of letters needed to complete it. The example below shows an item eliciting the word "bicycle":

Complete the underlined words as in the following example:

He was riding a bi He was riding a bicycle.

\section{Data Collection Procedures}

At the beginning of the study, The Placement Test was given to participants to answer in 30 minutes. The purpose of administering this test was to divide the participants into low and high level of proficiency. The maximum score on this test was 60 , and the participants with scores from 20 to 40 were placed in low proficiency group and those with score range of 40-60 were placed in high proficiency group. Before administering the two major vocabulary tests, both Receptive and Productive vocabulary levels tests were piloted in order to detect the probable problems and to estimate the time needed to complete the tests. The participants then took both of the tests separately with one-week interval between the two administrations. Of course, they were first given the receptive vocabulary test and then productive one, so that the students could not take advantage of the sentences of the productive test. Each test took about 30-45 minutes to be completed.

Therefore, three scores were calculated for each participant: the placement score, the receptive vocabulary score, and the productive vocabulary score. In scoring the passive vocabulary test, we gave each correct answer one point. Because the total number of items in the test is 150 , with 30 items at each frequency level, the maximum score for each level is 30 and for the whole test 150 . However, the test of productive vocabulary knowledge has the maximum score 18 for each frequency level and 90 for the whole test. The items on Productive test were marked as correct when semantically correct lexical item was provided in each blank. Furthermore, spelling errors that did not distort the word instead and wrong grammatical forms, for example the wrong tense, were marked as correct.

\section{Data Analysis}

The data obtained from the participants was analyzed using 22.0 version of the Statistical Package for Social Science (SPSS). First of all, the descriptive statistics was conducted on the scores of each group on the two vocabulary tests, and to illustrate the gap between participants' receptive and productive knowledge and its variation across proficiency level, the productive-receptive ratio 
was calculated. To check the relationship between the scores of the receptive and productive vocabulary tests, Pearson Product Moment correlation was used for the total scores and also for each separate frequency level in the tests. Furthermore, for examining whether the relationship between learners' receptive and productive vocabulary differs across different proficiency levels, an independent t-test was used.

\section{Results}

The first research question of the study concerns the nature of the relationship between Receptive and Productive vocabulary, and also whether this relationship is similar or different at low and high proficiency levels.
First of all, the descriptive statistics including the mean and standard deviation of the scores for the two tests in two groups of proficiency and also in the whole sample is represented in Table 1. Descriptive statistics has two functions: (1) it gives a precise description of the characteristics of a score distribution, and (2) it forms a basis for further statistical analyses in finding out the similarities and differences between and among sets of scores (Bachman, 2004). The raw scores for Receptive vocabulary size were out of 150 and for Productive vocabulary size are out of 90. However, for the ease of comparison all the scores in both tests were calculated out of 100 .

Table 1.

Descriptive Statistics for the Two Vocabulary Scores for Low and High Proficiency Levels and for the Whole Sample LP* HP** Whole Sample

\begin{tabular}{|c|c|c|c|c|c|c|c|c|c|}
\hline Vocabulary test & $\mathrm{N}$ & Mean & SD & $\mathrm{N}$ & Mean & SD & $\mathrm{N}$ & Mean & SD \\
\hline Receptive & 50 & 48.40 & 14.81 & 50 & 83.18 & 10.46 & 100 & 65.79 & 21.64 \\
\hline Productive & 50 & 33.11 & 10.20 & 50 & 60.82 & 13.20 & 100 & 46.96 & 18.21 \\
\hline
\end{tabular}

As it is shown in Table 1 and as it was expected, Receptive vocabulary of both low and high proficient learners and also for the whole sample was larger than Productive one. If one compares the mean scores of the low and high proficiency groups, he/she see that in both of the tests the mean scores of the high proficiency group are approximately two times larger than those of low proficiency group. Thus, the difference in the number of the words that learners know receptively as well as productively is somehow consistent across both proficiency levels. Furthermore, by taking a look at the above mentioned table, it can be seen that at the high proficiency level the difference in the mean scores of the two tests is larger than the low proficiency groups and even than the whole sample.

For having a clearer picture of the gap between the Receptive and Productive vocabulary size of the learners, the ratio (productive size/receptive size) of the productive to receptive vocabulary knowledge of each frequency band and also for the total score of the tests was also calculated and presented in Table 2 . Firstly, by looking at the ratio of the total scores, one can see that the Productive/Receptive ratio is higher in the high proficiency group, indicating a smaller gap between the two vocabulary types for this group in comparison to low proficiency group. Since it can be logically assumed that a smaller Receptive vocabulary consists of more frequent words and a larger Receptive vocabulary includes more infrequent words, the different $\mathrm{P} / \mathrm{R}$ ratios between the 2 groups may be due to the frequency of the words (Laufer \& Paribakht, 1998). Therefore, $\mathrm{P} / \mathrm{R}$ ratios at each frequency level are also presented in Table 2 below.

Table 2.

The Ratio of Productive to Receptive for the Total Scores of Vocabulary Tests and for each Frequency Level

\begin{tabular}{|c|c|c|c|}
\hline & Low proficiency & High Proficiency & Whole Sample \\
\hline Level 2000 & .53 & .57 & .56 \\
\hline Level 3000 & .48 & .49 & .47 \\
\hline Level 5000 & .22 & .36 & .31 \\
\hline Level 10000 & .08 & .25 & .22 \\
\hline Academic Level & .37 & .43 & .40 \\
\hline Total & .41 & .43 & .43 \\
\hline
\end{tabular}

Expectedly, both Receptive and Productive scores decrease with decreasing word frequency, but it does not occur at the same rate. As illustrated in Table 2, the P/R gaps within a learner's lexicon differ at various word 
frequency levels. The table above shows that by moving downwards from 2000 to 10000 frequency level, the ratio gets smaller in the whole sample and also in both proficiency groups, or in other words, the gap between Receptive and Productive vocabulary widens. In addition, it is clear that the learners had a higher $\mathrm{P} / \mathrm{R}$ ratio at academic frequency level than at the 5,000 level.

Another way to find out the relationship between Receptive and Productive vocabulary knowledge is to check their correlation or, in other words, how they vary together and whether the change in one of them leads to a change in the other or not. Before conducting the correlational test, the assumptions of the normality and equal variance for the whole sample on each of the two tests were checked, and since they were rejected, the nonparametric Spearman correlation test was used. Table 3 shows the result of Spearman correlation coefficients between receptive and productive vocabulary scores for each frequency band and also for total scores of the whole sample.

Spearman Correlations Coefficients between Receptive and Productive

Table 3. for each Frequency band and for Total Scores of the Whole Sample

\begin{tabular}{lccc}
\hline Frequency Levels & $r$ & $P$ value & $\mathrm{N}$ \\
\hline 2000 level & $.761^{* *}$ & .000 & 100 \\
3000 level & $.802^{* *}$ & .000 & 100 \\
5000 level & $.777^{* *}$ & .000 & 100 \\
10000 level & $.674^{* *}$ & .000 & 100 \\
Academic level & $.771^{* *}$ & .000 & 100 \\
Total Scores & $.907^{* *}$ & .000 & 100 \\
\hline
\end{tabular}

${ }^{*}$ Correlation is significant at the .05 level.

** Correlation is significant at the .01 level.

As shown in Table 3, the correlation coefficient obtained for the two tests in all frequency bands and also in the total scores is significant beyond the .01 level. The correlation between the total scores of the two tests is the strongest one $(r=.907, p=.000, N=100)$. Also, as seen in ratio results, the correlation between receptive and productive vocabulary knowledge at academic level is more than 10000 frequency level. In order to check the linearity of the relationship and also whether this relationship is positive or negative, the scatterplot for the scores obtained from the two tests is illustrated in Figure 1.

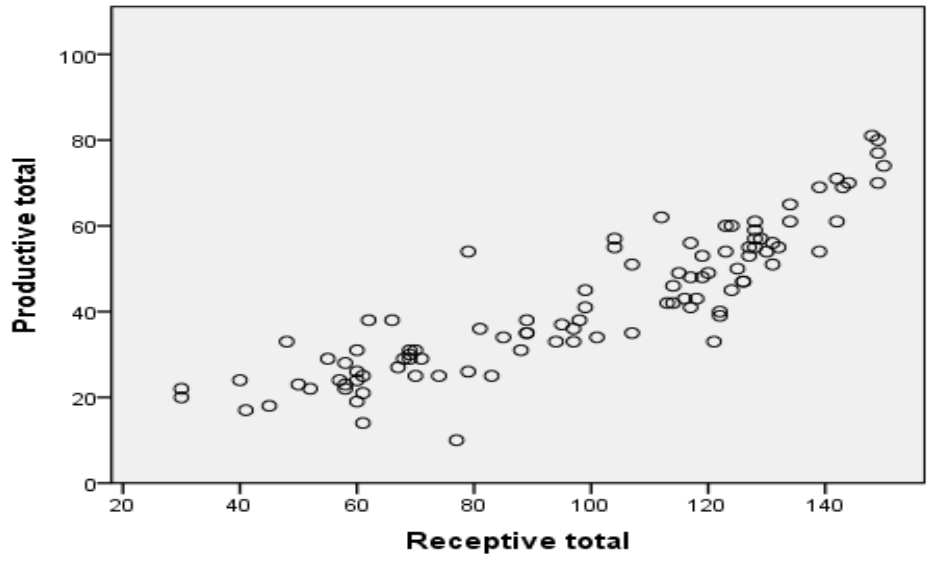

Fig. 1. Scatterplot of the Total Scores of Receptive and Productive Tests for the Whole Sample

As it can be seen, although the points do not lie in a perfect line, there is an obvious upward and positive direction with strong linearity effect size $(=0.78)$ in the presented data. This upward line shows that as the scores of the individuals in receptive test increase, their score in productive test also goes up. Additionally, for examining the relationship between receptive and productive vocabu- lary test scores (in each frequency band and in total) found in the whole sample, two additional correlational tests were conducted for each proficiency level separately. As the assumptions of normality and equal variances were satisfied, the parametric Pearson Product Moment Correlation test was utilized. The results of these correlational tests are shown in Table 4. 
Pearson's Product Moment Correlations Coefficients between Receptive and Productive for each Frequency Band and for Total Scores at the Low and High Proficiency Levels

Frequency Levels

Low Proficiency Level

\begin{tabular}{ccc}
$r$ & $p$ value & $\mathrm{N}$ \\
\hline $.376^{* *}$ & .007 & 50 \\
\hline $.543 * *$ & .000 & 50 \\
\hline $.469 * *$ & .001 & 50 \\
\hline .180 & .211 & 50 \\
\hline $.411 * *$ & .003 & 50 \\
\hline $.702 * *$ & .000 & 50
\end{tabular}

High Proficiency Level

\begin{tabular}{ccc}
$r$ & $p$ value & $\mathrm{N}$ \\
\hline $.485^{* *}$ & .000 & 50 \\
\hline $.573 * *$ & .001 & 50 \\
\hline $.489 * *$ & .000 & 50 \\
\hline $.803 * *$ & .000 & 50 \\
\hline $.534 * *$ & .000 & 50 \\
\hline $.786 * *$ & .000 & 50
\end{tabular}

Correlation is significant at the .05 leve

** Correlation is significant at the .01 level.

As shown in Table 4, there is a significant correlation between the total scores of receptive and productive tests at both low $(\mathrm{r}=0.702, \mathrm{p}=0.000, \mathrm{~N}=50)$ and high $(\mathrm{r}=$ $0.786, \mathrm{p}=0.000, \mathrm{~N}=50$ ) prificiency levels beyond the .05 level, and also the correlation in high proficiency group is slightly higher than the low proficiency group in total scores. Regarding the frequency levels, in each band the correlation in high proficiency group is higher than the low proficiency group which means that at high proficiency level more receptively known words are also known productively.
Also at both proficiency levels the correlation at 2000 frequency level is less than the other frequency levels unexpectedly. Furthermore, very interestingly it is seen that at 10000 frequency level there is a very strong correlation $(\mathrm{r}=0.803, \mathrm{p}=0.000)$ between receptive and productive scores among high proficient learners while there is no significant correlation $(r=0.180, p=0.211)$ at this frequency level among low proficient learners. To see the linearity and direction of these relationship visually, two scatterplots, one for low proficiency level and one for high proficiency level, are illustrated in Figure 2 and Figure 3 respectively.

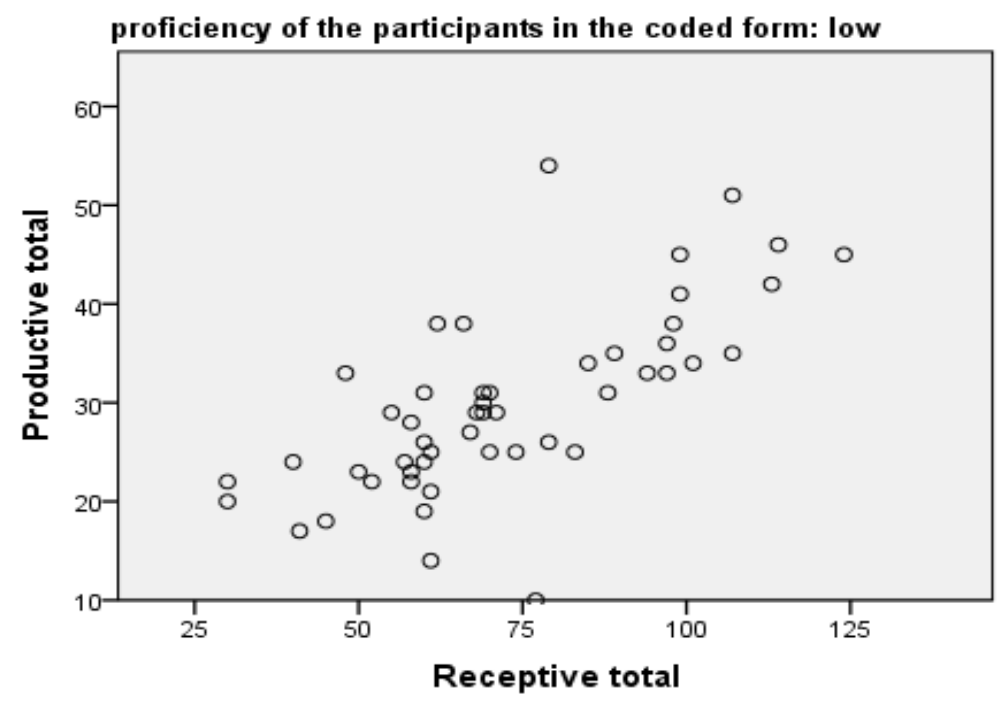

Fig. 2. Scatterplot of the Total Scores of Receptive and Productive Tests for the Low Proficiency Level 


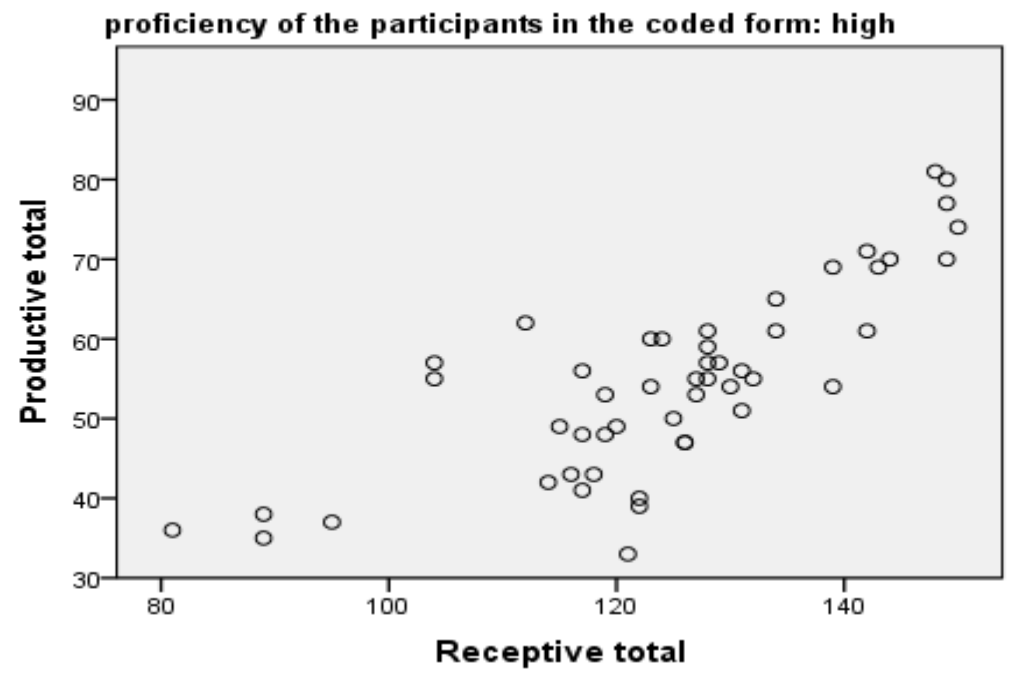

Fig. 3. Scatterplot of the Total Scores of Receptive and Productive Tests for the High Proficiency Level

Like the scatterplot for the whole sample results, the linear and positive directions of the two sets of scores for receptive and productive vocabulary tests in both scatterplots are illustrated. The strength value of the linearity or effect size for low and high proficiency levels are $=0.49$ and $=0.61$ respectively which shows stronger relationship between receptive and productive vocabulary knowledge of high proficient learners.

The second research question of the present study is whether the relationship between learners' Receptive and Productive vocabulary differs significantly across differ- ent proficiency levels. In order to answer this question, the Productive to Receptive ratio, which is indicative of Productive/Receptive relationship, for all the individual scores on both tests and for both proficiency level was calculated. Then, to examine if there was any significant difference in these ratios between low and high proficiency groups, an independent t-test was conducted on the related data. The mean scores and standard deviations of the ratio scores at both proficiency levels alongside the ttest results are presented in the Table 5 below.

Table 5.

Independent Samples T-Test Results Comparing Low and High Groups' Productive/Receptive Ratio Means

\begin{tabular}{lllllll}
\hline & Mean & SD & $\begin{array}{l}\text { Mean } \\
\text { Difference }\end{array}$ & $t$ & df & Sig. \\
\hline Low & .426 & .114 & -.010 & -.578 & 75.48 & .565 \\
High & .436 & .061 & & & &
\end{tabular}

As shown in Table 5, no significant and meaningful difference between low proficiency group ( $M=0.426$, $\mathrm{SD}=0.114)$ and high proficiency group $(\mathrm{M}=0.436$, $\mathrm{SD}=0.061)$ in the Receptive/Productive relationship was found $(\mathrm{p}=0.565, \mathrm{p}>0.05)$. Thus, the proficiency level did not make any difference in the nature of the relationship between Receptive and Productive vocabulary knowledge of the learners.

\section{Discussion}

The findings confirmed the general perception that learners' Receptive (R) vocabulary is larger than their Productive $(\mathrm{P})$ one and also showed that learners with larger $\mathrm{R}$ vocabularies also had larger $\mathrm{P}$ vocabularies. Also, based on the ratio results, the gap between $\mathrm{R}$ and $\mathrm{P}$ vocabulary widens as the frequency of words decreases. These results confirm the findings of most of the previously done studies (e.g. Laufer \& Paribakht, 1998; Nemati, 2010; Webb, 2008). For instance, Webb (2008) indicated that total $\mathrm{R}$ vocabulary size was larger than $\mathrm{P}$ vocabulary in total and also in each of word frequency bands, with the difference between Receptive and Productive knowledge increasing as the frequency of the words decreased. Webb (2008) indicated that Receptive vocabulary size might give some indication of Productive vocabulary size. Learners who have a larger receptive vocabulary are likely to know more of those words productively than learners who have a smaller receptive vocabulary. Also, the higher $\mathrm{P} / \mathrm{R}$ ratio at academic frequency level in comparison to the 5,000 and 10,000 level can be justified in this way that academic frequency level consists of words from 4,000 to 6,000 frequency levels, so academic words are not less frequent than the words at the 5,000 level (Laufer \& Paribakht, 1998). All in all, the higher the frequency of the receptive words in the learner's lexicon, the smaller the R/P gap. Hence, less frequent words are 
less likely to be part of the learner's Productive vocabulary use.

The comparison of the ratios at the low and high proficiency levels showed that the $\mathrm{P} / \mathrm{R}$ ratio is higher in the High proficiency group, indicating a smaller gap between the two vocabulary types for this group in comparison to low proficiency group and the whole sample. This means that the gap between the two types of knowledge has decreased at higher levels of language proficiency.

This result is in line with the result found by Nemati (2010) while it is in contrast with Laufer (1998) and Laufer and Paribakht (1998) findings related to EFL context. They found that the gap widened somewhat as EFL learners acquired more vocabulary. However, it should be mentioned that in the current study the difference in $P / R$ ratio found between two proficiency groups is very slight.

The other interesting point found in comparing low and high groups' ratios at all frequency levels was that although the $\mathrm{P} / \mathrm{R}$ ratio in high proficiency group was more than low proficiency one, this difference at 5000 and $10000(0.36-0.22$ and $0.25-0.08)$ frequency levels was much more than other levels. Put it in simpler words, as learners gain higher proficiency level in English, the number of less frequent receptive words that change into productive use increases while it is not the case with lower proficient learners. It can be said that learners at both HP and LP levels can use most of the frequent receptive words productively too, but as the frequency of the words decreases this interface between receptive and productive vocabulary occurs more often among high proficient learners rather than their low proficient counterparts.

Furthermore, the results of the correlation test for the whole sample indicated a positive relationship between the receptive and productive vocabularies. However, regarding the strength of the correlations at different frequency levels of the whole sample, it was found that the correlation coefficient in 2000 was less than frequency levels of 3000,5000 , and academic in contrast to our expectation. This result which was not found in previous studies can be justified by the EFL context that Iranian learners learn vocabularies. The frequent words (word at 2000 frequency level) are the ones usually heard and used in every-day language in the target community, and Iranian EFL learners come across with these words just in the communicative course books being taught in language institutes which are usually written by native authors, or in the movies. Therefore, these learners can get these vocabularies receptively while they do not have any opportunity to use them productively due to the foreign language context. Except for 2000 frequency level, the findings for other frequency levels were somehow similar to the ratio results already discussed in a way that as the frequency level decreases (from 3000 to 10000 frequency band), the correlation coefficient also decreases. This finding disconfirms the findings of Nemati (2010) who reported the correlation increases as we move towards higher word levels like 5000 and Academic word levels including low frequency words. In general, it can be con- cluded that due to a strong relationship between Receptive and Productive vocabulary knowledge, a change in one form of the vocabulary knowledge leads to change in the other form too.

Furthermore, it can be seen that at 10000 frequency level there was a very strong correlation between Receptive and Productive scores among high proficient learners while there is no significant correlation among low proficient learners. This means that there is a big gap between $\mathrm{R}$ and $\mathrm{P}$ knowledge of how proficient learners, but as they learn more and improve their proficiency level, this gap is bridged since more Receptive or passive vocabularies turn into Productive or active form. In most of the previous studies the 10000 frequency level section of the test are excluded since it was beyond the knowledge of participants of those studies. However, this frequency level was used in the present study because it was aimed to see the difference between low and high proficient leaners in the Receptive and Productive knowledge of less frequent words in English.

Finally, according to T-Test results, the proficiency level was found not to make any significant difference in the relationship between receptive and productive vocabulary knowledge of the learners. This finding is consistent with Nemati's (2010) results that although the gap between passive and active vocabulary decreased and the students had some improvement, years of instruction did not have a significant influence on controlled active vocabulary knowledge.

\section{Conclusions}

This study attempted to examine the relationship between learners' receptive and productive vocabulary knowledge as a whole and at different frequency bands. Also, it was investigated whether the relationship between learners' receptive and productive vocabulary differs significantly across different proficiency levels. The results of the study indicated that there is a significant correlation between receptive and productive vocabulary tests' total scores as well as scores at each frequency level for the whole sample. Regarding the two proficiency levels, the same result was found except for 10000 frequency level scores of low proficient learners. In addition, it was figured out that the relationship between learners' $\mathrm{R}$ and $\mathrm{P}$ vocabulary does not differ significantly across different proficiency levels.

The present research can have some implications for both language teachers and syllabus designers. Helping students to turn their Receptive vocabularies into Productive forms to be able to use them in communication in the target language has always been an important issue for teachers. As shown in this study, the proficiency level of the learners did not make any significant difference in $P / R$ relationship though the size of both improved from low to high proficiency level. Therefore, although EFL context is an important impeding factor in changing of Receptive vocabularies into Productive ones, the amount of instruction in teaching/learning context from low to high proficiency level did not have much effect in improving of the 
learners' Productive vocabulary knowledge. The activation of passive vocabulary largely depends on multiple exposures to words and opportunities to use them, conditions absent in the EFL context; therefore, EFL teachers and syllabus designers need to rely on some methods, tasks, and activities (e.g. pushed output) to provide a good condition for the learners to be encouraged to use the vocabularies actively.

\section{REFERENCES}

1. Alderson, J. C. (2005). Diagnosing foreign language proficiency. London: Continuum.

2. Anderson, R.C., \& Freebody, P. (1981). Vocabulary knowledge. In J.T. Guthrie (Ed.). Comprehension and teaching: Research reviews. Newark, DE: International Reading Association.

3. Bachman, L. F. (2004). Statistical analyses for language assessment. Cambridge: Cambridge University Press.

4. Corson, D.J. (1995). Using English words. Dordrecht: Kluwer Academic Publishers.

5. Crow, J.T. (1986). Receptive vocabulary acquisition for reading comprehension. Modern Language Journal, 70, 242-250.

6. Fan, M. (2000). How big is the gap and how to narrow it? An investigation into the active and passive vocabulary knowledge of L2 learners. RELC Journal, 31(2), 105-119.

7. Harrington, M., \& Carey, M. (2009). The on-line Yes/No test as a placement tool. System, 37(4), 614-626.

8. Henriksen, B. (1999). Three dimensions of vocabulary development. Studies in Second Language Acquisition, 21(2), 303-317.

9. Henriksen, B., \& Haastrup, K. (1998). Describing learners' lexical competence across tasks and over time: A focus on research design. In K. Haastrup, \& A. Viberg (Eds.). Perspectives on lexical acquisition in second languages (pp. 61-95). Sweden: Lund University Press.

10. Hilton, H. (2008). The link between vocabulary knowledge and spoken L2 fluency. Language Learning Journal, 36(2), 153-166.

11. Klein-Braley, C., \& Rattz, U. (1984). A Survey of research on the C-test. Language Testing, 1(2), 134146.

12. Laufer, B. (1992). How much lexis is necessary for reading comprehension? In Arnaud, P.J.L. and Béjoint, H. (eds.), Vocabulary and Applied Linguistics (pp. 126-132). London: Macmillan.

13. Laufer, B. (1998). The development of passive and active vocabulary: Same or different? Applied Linguistics, 19, 255-271.

14. Laufer, B. (2005). Lexical frequency profiles: From Monte Carlo to the real world. A response to Meara (2005). Applied Linguistics, 26(4), 582-588.

15. Laufer, B., Elder, C., Hill, K., \& Congdon, P. (2004). Size and strength: Do we need both to measure
This study also suffers from some limitations. One of them is that the data of the study was confined merely to two proficiency levels and in an EFL environment. Another limitation was not measuring the free active vocabulary size. Therefore, further studies with different participants and in different environments with different proficiency levels are also recommended. Making use of further measures of vocabulary knowledge is also recommended.

vocabulary knowledge? Language Testing, 21(2), 202226.

16. Laufer, B., \& Goldstein, Z. (2004). Testing vocabulary knowledge: Size, strength, and computer adaptiveness. Language Learning, 54(3), 399-436.

17. Laufer, B., \& Nation, P. (1995). Vocabulary size and use: Lexical richness in $\mathrm{L} 2$ written production. Applied Linguistics, 16(1), 307-322.

18. Laufer, B., \& Nation, P. (1999). A vocabularysize test of controlled productive vocabulary. Language Testing, 16(1), 33-51.

19. Laufer, B., \& Paribakht, T. S. (1998). The relationship between passive and active vocabularies: Effects of language learning context. Language learning, 48(3), 365-391.

20. Meara, P. (1990). A note on passive vocabulary. Second Language Research, 6, 150-154.

21. Melka, F. (1997). Receptive vs. productive aspects of vocabulary. In N. Schmitt, \& M. McCarthy (Eds.). Vocabulary: Description, acquisition, and pedagogy (pp. 84-102). Cambridge: Cambridge University Press.

22. Milton, J. (2009). Measuring second language vocabulary acquisition. Clevedon: Multilingual Matters.

23. Nation, P. (1983). Testing and teaching vocabulary. Guidelines, 5(1), 12-25.

24. Nation, P. (1990). Teaching and learning vocabulary. Mass.: Newbury House.

25. Nation, P. (2001). Learning vocabulary in another language. Cambridge: Cambridge University Press.

26. Nation, P. (2006). How large a vocabulary is needed for reading and listening? Canadian Modern Language Review, 63(1), 59-82.

27. Nemati, A. (2010). Active and passive vocabulary knowledge: The effect of years of instruction. Asian EFL Journal, 12(1), 30-46.

28. Pignot-Shahov, V. (2012). Measuring L2 receptive and productive vocabulary knowledge. Language Studies Working Papers, 4, 37-45.

29. Qian, D. D., \& Schedle, M. (2004). Evaluation of an in-depth vocabulary knowledge measure for assessing reading performance. Language Testing, 21, 28-52.

30. Read, J. (2000). Assessing vocabulary. Cambridge: Cambridge University Press.

31. Schmitt, N. (2010). Researching vocabulary: A vocabulary research manual. London: Palgrave Macmillan. 
32. Schmitt, N., Schmitt, D., \& Clapham, C. (2001). Developing and exploring the behaviour of two new versions of the Vocabulary Levels Test. Language Testing, $18(1), 55-88$.

33. Stæhr, L. S. (2009). Vocabulary knowledge and advanced listening comprehension in English as a foreign language. Studies in Second Language Acquisition, 31(4), 577-607.

34. Webb, S. (2008). Receptive and productive vocabulary sizes of L2 learners. Studies in Second Language Acquisition, 30(1), 79-95.

35. Wei, M. (2007). An examination of vocabulary learning of college level learners of English in China. Asian EFL Journal, 9(2), 93-114.
36. Wilkins, D.A. (1972). Linguistics in language teaching. London: Arnold.

37. Yu, G. (2010). Lexical diversity in writing and speaking task performances. Applied Linguistics, 31(2), 236-259.

38. Zhong, H. (2012). Multidimensional vocabulary knowledge: Development from receptive to productive use. In D. Hirsh, (Ed.). Current perspectives in second language vocabulary research. Berlin: Peter Lang.

39. Zhong, H., \& Hirsh, D. (2009). Vocabulary growth in an English as a foreign language context. University of Sydney Papers in TESOL, 4, 85-113.

Сімін Cammapnyp, кандидат педагогічних наук, кафедра іноземних мов,

Тебризький університет, 29, бул. Бахман, м. Тебріз, Іран

\section{ВПЛИВ РІВНЯ ВОЛОДІННЯ АНГЛІЙСЬКОГО МОВОЮ НА АКТИВНИЙ ТА ПАСИВНИЙ СЛОВНИКОВИЙ ЗАПАС СТУДЕНТІВ}

Перетворення пасивного словникового запасу студентів у його активну форму з метою використання його в мовленні завжди залишалося важливим питанням для вчителів. Статтю присвячено вивченню взаємозв'язку між активним і пасивним словниковим запасом у цілому та у різних частотних діапазонах у межах двох рівнів володіння англійською мовою: низьким та високим. У дослідженні взяли участь 100 студентів, які вивчають англійську як іноземну. Респонденти пройшли А-версію Тесту на визначення рівня активного та пасивного словникового запасу. Було визначено, що пасивний словниковий запас у студентів як правило більше активного, і ця різниця збільшувалася у міру того як частота слів у тесті зменшувалася. Як показало дослідження, рівень володіння англійською мовою значно не впливає на співвідношення пасивного та активного словникового запасу, хоча об'єм обох словникових запасів є більшим у студентів із високим рівнем володіння англійською мовою. Отже, незважаючи на те, що контекст викладання англійської мови як іноземної є фактором, який ускладнює перехід лексики 3 пасивного словникового запасу в активний, кількість уроків англійської мови суттєво не впливає на якість засвоєння студентами активного словникового запасу. Активація пасивного словникового запасу значною мірою залежить від багаторазового використання в мовленні слів, що вивчаються, в ситуаціях поза межами навчального процесу; таким чином, викладачам англійської мови як іноземної та розробникам навчальних програм 3 англійської мови слід використовувати такі методи навчання, завдання та види діяльності, які б створювали сприятливі умови для активного використання лексики, що вивчається. Дослідження може представляти інтерес як для вчителів англійської мови, так і для розробників навчальних програм.

Ключові слова: пасивний словниковий запас, активний словниковий запас, тест на визначення рівня словникового запасу, англійська як іноземна, студенти.

Submitted on February, 23, 2017 